\title{
OECD report itemizes risks of renewable energy production
}

Paris

ENVIRONMENTALISTS have been campaigning for years to alert governments to the long-term risks of burning fossil fuels for energy production, but the so-called 'clean' alternatives of wind, wave, solar power and geothermal power are not without serious hazards, according to a report from the Organisation for Economic Cooperation and Development (OECD).

The report takes the "important positive aspects" of renewable energy use as given. But while the negative impacts of fossil fuels or nuclear energy may be longterm and planet-wide, those of renewables tend to be more localized and shorter-term. In most cases, they arise because renewable sources convert low energy densities and thus require huge collector areas. Hydroelectric power, which accounts for 21 per cent of energy production in OECD countries (1978 figures), like wind power, is not directly polluting, but may render large areas unusable for agriculture or recreation and can destroy local ecosystems.

Biomass, especially firewood, which accounts for about 20 per cent of energy produced in developing countries can, however, have serious environmental impacts. Apart from deforestation, with its risks of soil erosion, burning firewood can produce airborne, inhalable particles that may be carcinogenic, as well as greenhouse gases. Large-scale waste incineration, on the other hand, is only as clean as the material burned. If the waste stream contains plastics or chlorinated products, highly toxic and often halogen- ated compounds may be produced, including dioxin and hydrochloric acid.

If passive solar energy presents few risks, apart from the build-up of radon due to improved insulation, active solar energy panels contain potentially dangerous chemicals, such as biocides, rustinhibitors and antifreeze that could pose a

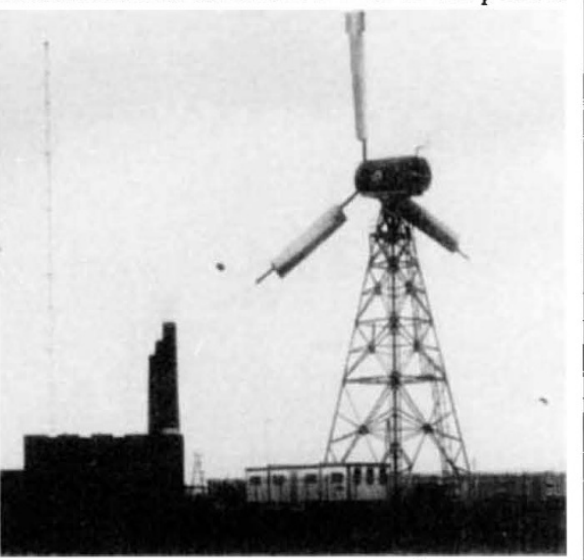

Good news but not if you are too close. . . This was the first wind-turbine from Britain's $C E G B$. problem for disposal on a large scale, says the report.

Geothermal energy also poses risks. Hydrogen sulphide and benzene are almost always associated with high-temperature geothermal fluids in large volumes and there is also an unknown risk that reinjected geothermal fluids could induce seismic activity - and most geothermal sites are in sesimically active regions.

Peter Coles

Environmental Impacts of Renewable Energy. The OECD Compass Project. OECD 1988.

\section{Indo-French agreement stresses vaccines}

\section{New Delh}

A MAJOR Indo-French agreement on medical research is due to be signed in February on the eve of the visit of French President François Mitterrand to New Delhi to open the year-long festival of France in India. The agreement will be between the Indian Council of Medical Research and the French Health and Medical Research Institute (INSERM).

Seven research areas will be covered: fertility and human reproduction, ophthalmology, nutrition, public health, epidemiology, virology, immunology and bioengineering. Collaboration will be on equal terms and will include exchange of scientists, sharing of information and the initiation of research projects. The agreement will continue the trend towards increased collaboration between India and France.

An Indo-French Centre for Advanced Research set up in New Delhi in 1987 has already given shape to 14 joint projects. It will soon have a building of its own, constructed by France and given to India as part of the festival.

Another collaborative venture for the manufacture of vaccines is taking shape. It involves the construction of a plant to mass produce vaccines against measles, polio and rabies, and a multiple vaccine, in Gurgaon, on the outskirts of New Delhi, by the Institut Merieux of Lyons. The plant will at first meet the demands in India and later be expanded to cater to neighbouring countries.

Collaboration on vaccine production is important in the context of India's mission to immunize all children against six diseases by 1992. Another plant for producing 100 million doses of oral polio vaccine is being set up at Bulandshar, 140 kilometres from Delhi, in collaboration with the Soviet Union.

\section{Reactor restarts sans repair}

Paris

THE French prototype fast-breeder nuclear reactor, Superphénix, is to be restarted after a 20-month shut-down, even though its leaking fuel-rod transit chamber has not yet been modified (see Nature 332, 384; 1988). The news, published in the government archive Journal Officiel last week, follows an announcement by the Industry Minister, Roger Fauroux.

The decision was greeted with applause by the 200 employees at the reactor's Creys-Malville site, near Lyons. But ecology action groups in France and neighbouring Switzerland are outraged and will now seek legal help to try to shut down the reactor permanently.

Superphénix was closed in March 1987 when liquid sodium coolant was found to be leaking from a storage and transit chamber. Engineers from Electricité de France (EDF), the nationalized utilities company that runs Superphénix, found fissures in the inner lining of the chamber. They proposed replacing the sodium coolant with inert argon gas and then running the reactor without the transit chamber inner lining in place. As the core is already charged with fuel, says EDF, the reactor can be run safely for about a year without needing to use the transit chamber. In the meantime, the chamber can be modified.

Fauroux was planning to restart the reactor on 14 January. If there are no incidents, electricity generation could begin again in March.

Critics feel that it is irresponsible to restart the reactor with one of its original safety devices out of action. Should an accident occur within the core, the transit chamber is the only place where fuel rods can safely be stored. They argue that Superphénix is not actually needed for electricity generation and is essentially a full-scale simulator for engineers.

Environmentalists say the government's action is undemocratic. "The decision was designed to have a psychological impact, to demoralize the opposition", says René Longet, director of the Swiss Association for the Protection of the Environment. "Why cannot the French allow open debate on nuclear energy, like other European countries?", he asks. France appears increasingly isolated now that both Britain and West Germany have effectively abandoned their fast-breeder programmes. But France, too, is under internal pressure, mostly economic, and has shelved plans to build a sister to Superphénix. The Centre à l'Energie Atomique, however, remains adamant that it is essential to gain technical expertise at Creys-Malville. 